\title{
Biografie van professor Sarel Jacobus van der Merwe
}

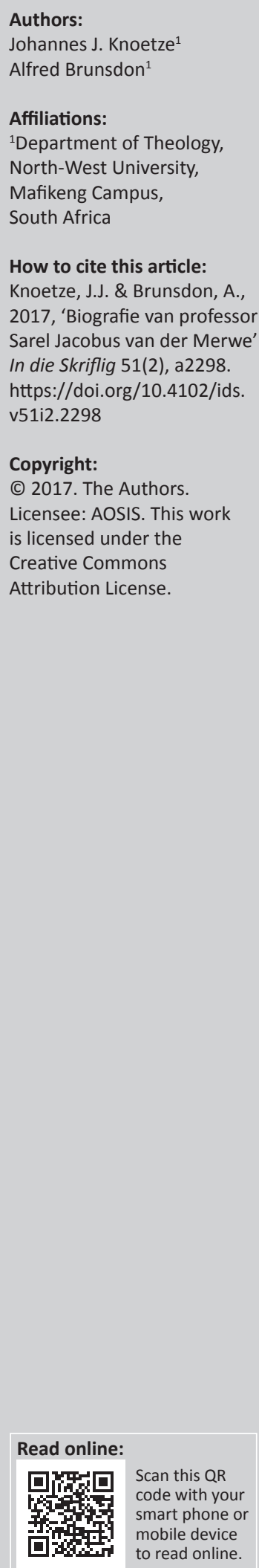

\section{Inleiding}

Dit was inderdaad 'n besondere voorreg om die biografie vir die festschrift van ons kollega en vriend, professor Sarel van der Merwe, ter viering van sy lewe en akademiese loopbaan te skryf. Aangesien ons bevoorreg was om 'n aantal jare in noue verband saam met Sarel te werk, maak hierdie biografie geensins aanspraak op objektiwiteit nie. Dit moet eerder as 'n persoonlike dokument gelees word wat uit biografiese inligting saamgestel en met ons persoonlike waarnemings en belewenisse van Sarel oor die afgelope jare gekombineer is. Ons vertrou egter dat dit aan die lesers 'n getroue oorsig van sy lewe en werk sal bied, terwyl dit ook erkenning verleen aan die groot taak wat hy tydens sy loopbaan verrig het.

\section{Jeug, roeping en studie}

Sarel is op 1 November 1948, as die vyfde kind van Demps en Annie van der Merwe, te Pietersburg (nou Polokwane) gebore. Van sy eerste herinnerings was dié aan sy sendeling-vader wat eers in Namibië (toe Suidwes-Afrika) gewerk het en later professor in Missiologie aan die Teologiese Skool te Potchefstroom geword het. Na voltooiing van sy skoolloopbaan aan Potchefstroom Gimnasium, gee Sarel gehoor aan sy roeping om predikant te word. Hy skryf in by die Potchefstroomse Universiteit vir Christelike Hoër Onderwys in 1968 en behaal die graad Baccalaureus Artium in 1970, met Filosofie en Logika as hoofvakke. In die daaropvolgende jare sit hy sy studie aan die Teologiese Skool te Potchefstroom voort en behaal die graad Theologiae Baccalaureus in 1974 asook sy kandidaatsertifikaat wat hom tot die bediening as leraar in die Gereformeerde Kerke van Suid-Afrika toelaat.

\section{Gemeentelike bediening en vroeë akademiese loopbaan}

Sarel is in 1975 as leraar van die kombinasiegemeente Keetmanshoop en Karasburg bevestig, wat hy tot 1978 bedien het. Later in dieselfde jaar ontvang Sarel 'n beroep as leraar en sendeling van die Gereformeerde Kerk Kuruman, waarna hy na Suid-Afrika terugkeer om in Kuruman tot 1982 te arbei. In 1982 is hy ook as sendeling onder die Tswana-sprekendes, in diens van die Duineveldgemeente te Hotazel in die Kudumane-distrik bevestig.

Gedurende hierdie periode besluit Sarel om sy studie in die Teologie voort te sit en hy behaal in 1987 die graad Theologiae Magister (cum laude) asook die graad Philosophiae Doctor in Missiologie in 1993. Tydens sy meestersgraadstudie het Sarel op ' $n$ missiologiese assessering van die dramatisering van bybelse materiaal as sendingmetode gefokus. Sy doktorale studie het op die assessering van radio en televisie as missiologiese mediums in Suid-Afrika gefokus.

Kort nadat hy sy meestersgraad verwerf het, het Sarel aktief by die opleiding van predikante as deeltydse dosent by Sekolo sa Mojadi ${ }^{1}$ in Mareetsane betrokke geraak. Hierdie was'n sendingprojek van die Gereformeerde Gemeenten in Nederland, gerig op die opleiding van evangeliste vir sendingwerk onder Tswana-sprekendes. ${ }^{2}$

Met die aanbreek van die nuwe demokrasie in 1994, het daar ingrypende veranderings in die hoër onderwysstelsel ingetree wat uiteindelik ook 'n invloed op Sarel se akademiese loopbaan sou hê. Een hiervan was die sluiting van die Teologiese Skool te Hamanskraal, waar swart leraars uit die Gereformeerde Kerke van Suid-Afrika hulle predikantsopleiding ontvang het. Gevolglik het die Fakulteit Teologie in Potchefstroom aktief vennootskappe met teologiese kolleges gesoek ten einde hulle akademiese program uit te brei. Daar is 'n vennootskap tussen die Fakulteit Teologie

\section{Die Tswana uitdrukking beteken 'Skool van die Saaier'.}

2.Vir 'n gedetailleerde geskiedenis van die Sekolosa Mojadi, sien Brunsdon, A. \& Van der Merwe, S.J., 2013. 'From Mojadi to Mafikeng Notes on the newfound Department of Theology', Studia Historiae Ecclesiasticiae 39(1), 295-313. 
in Potchefstroom en die Sekolo sa Mojadi aangegaan om die Fakulteitsgraad in Mareetsane aan te bied. Om hierdie vennootskap te fasiliteer, is die personeel van Sekolo sa Mojadi geakkrediteer en in 1996 verander die naam van Sekolo sa Mojadi na College ya Mojadi. Hiermee het Sarel se akademiese verantwoordelikhede toegeneem, aangesien hy nou 'n geakkrediteerde dosent van die Fakulteit Teologie was. Gegewe die feit dat College ya Mojadi 'n behoefte aan 'n driejarige teologiese graad gehad het-eerder as 'n sewejarige kwalifikasie soos deur die Fakulteit aangebied - het Sarel ook by die ontwikkeling van ' $n$ driejarige BA-graad in Teologie betrokke geraak. Sarel word ook die prinsipaal van College ya Mojadi tot en met 2005

'n Tweede belangrike verandering wat Sarel se loopbaan beïnvloed het, was die samesmelting van die Potchefstroomse Universiteit vir Christelike Hoër Onderwys, die Universiteit van Noordwes in Mmabatho en die Vista Universiteit in Sebokeng in 2004 om die huidige Noordwes-Universiteit te vorm. Dit het 'n geleentheid vir die Fakulteit Teologie op Potchefstroom gebied om die moontlikheid van 'n amptelike Teologie Departement op die Mafikengkampus van die nuutsaamgestelde universiteit te ondersoek.

\section{Voltydse akademiese loopbaan en die vestiging van 'n Departement Teologie op die Mafikengkampus van die Noordwes-Universiteit}

As gevolg van Sarel se betrokkenheid by College ya Mojadi en die feit dat hy met die akademiese programme te Potchefstroom vertroud was, was hy die aangewese persoon om 'n strategiese vennoot in die vestiging van 'n Teologie Departement op die Mafikengkampus te word. Dit gee aanleiding daartoe dat Sarel in 2006 as medeprofessor in Missiologie op die Potchefstroomkampus van die Noordwes-Universiteit aangestel word, met die opdrag om 'n Departement Teologie op Mafikeng te vestig. Met 'n ware pioniersgees aanvaar Sarel die uitdaging en vestig homself in Mafikeng. Met die nodige oorleg en kundigheid het hy die daaropvolgende onderhandelings en prosesse bestuur en in 2011 open die nuwe Departement Teologie amptelik sy deure binne die Fakulteit van Menslike en Sosiale Wetenskappe op die Mafikengkampus.

Alhoewel die totstandkoming van die Departement vir Sarel 'n persoonlike hoogtepunt verteenwoordig het, sou dit uiteindelik ook'n groot impak op sy eie akademiese loopbaan hê deur dit in 'n nuwe rigting te stuur. Omdat Sarel sedert 2006 alleen die proses op Mafikeng gedryf het, het dit onder andere meegebring dat hy die hele program akademies, administratief en bestuursgewys persoonlik moes bestuur. Dit is dus verstaanbaar dat daar min tyd vir sy persoonlike akademiese ontwikkeling oorgebly het. Dit het beteken dat hy selde die voorreg gehad het om navorsingsverlof te neem of konferensies op 'n gereelde basis byte woon. Hiermee saam het aandklasse vir die groeiende groep studente hom nog tot laataand op die kampus gehou. Sarel kon eers in 2010 die luukse bekostig om deeltydse dosente aan te stel wat hom met die onderrigleerverantwoordelikhede kon bystaan. Ten spyte van die swaar onderriglading, het Sarel steeds daarin geslaag om voordragte by konferensies te lewer en van sy navorsing te publiseer.

As programleier van Teologie op Mafikeng het Sarel sedert die stigting van die Departement dus op onderrig, administrasie en bestuur gefokus. Hy het egter ook nagraadse studente van die Potchefstroomkampus in die Missiologie begelei, asook studente van die Mafikengkampus wat verder studeer het. Met die groei van die Departement is daar onder Sarel se leiding in 2012 nog twee voltydse personeellede aangestel, waarvan die getal in 2017 na vier voltydse personeellede gegroei het.

Oor die volgende jare het Sarel die fakkeldraer van Teologie op die Mafikengkampus geword, deurdat hy op verskeie vlakke en in verskillende forums op die kampus en ook in die wyer gemeenskap gedien het. Hy het 'n goeie verhouding met die kampusbestuur gehandhaaf en is in Augustus 2013 gevra om as waarnemende skooldirekteur vir die Skool van Menslike Wetenskappe op te tree. 'n Pos wat hy tot en met sy aftrede aan die einde van 2014 gevul het. Ten spyte van groot uitdagings verbonde aan die pos, het Sarel daarin geslaag om 'n sigbare verskil in die produktiwiteit van die Skool te weeg te bring, veral wat die navorsingsuitsette van personeel gedurende hierdie periode betref.

Aan die einde van 2014 het Sarel die voorgeskrewe aftreeouderdom vir personeel van die Noordwes-Universiteit bereik. As die geliefde en gerespekteerde 'Vader van Teologie' op die Mafikengkampus, was Sarel traag om sy kantoor op die kampus vir sy kantoor by sy woning te verruil. Dit het egter nie die einde van sy betrokkenheid by die Departement beteken nie, aangesien Sarel steeds aktief by die begeleiding van nagraadse studente betrokke is. Hy leef ook sy liefde vir onderrig steeds uit deur die aanbieding van lesings by die Eenheid vir Oop Afstandsleer waar hy modules in die $\mathrm{Ou}$ Testament vir voorgraadse en Honneurs-studente aanbied.

\section{Kerklike en gemeenskapsbetrokkenheid}

Behalwe die gemeentes wat reeds genoem is, het Sarel ook tydens sy akademiese loopbaan 'n voortgaande en betekenisvolle bydrae tot die breë gemeenskap van die Gereformeerde Kerke van Suid-Afrika gemaak. Dit is duidelik uit sy verkiesing as voorsitter van die streek- sowel as die nasionale sinodes by meer as een geleentheid. Hy het ook leiding geneem as voorsitter van verskeie studiekommissies wat onder andere getaak was om sosiale probleme en leerstellige kwessies te ondersoek. Hy dien ook verskeie jare op die kuratorium van die Gereformeerde Kerke van SuidAfrika wat die verantwoordelikheid het om toesig oor die opleiding van die leraars van die Gereformeerde Kerke te hou.

Sedert sy verhuising na Mafikeng het Sarel ook die verantwoordelikheid as gemeenteleraar van die Gereformeerde 
Kerk Mafikeng oorgeneem, insluitend die lei van eredienste en die bediening in die naburige Botswana. Dit het meegebring dat Sarel op Sondae verskillende preekpunte moes beman en groot afstande afgelê het, voordat hy weer op Maandae sy akademiese verpligtings moes nakom. Die betrokkenheid binne die gemeentelike praktyk was egter iets waarop Sarel 'n hoë premie geplaas het, ter wille van die toerusting van sy studente.

As iemand met 'n hart vir sending, was Sarel deurentyd ook in die gemeenskappe waar hy gewoon het, betrokke. Hiervan getuig sy betrokkenheid by talle MIV- en VIGS-programme wat in plattelandse gemeenskappe op die been gebring is. Hy het ook 'n groot belangstelling in die bemagtiging van die jeug van die verskillende kulture getoon, ten einde jongmense tot selfstandigheid te lei om so armoede te help verlig. Tans vertolk Sarel ook steeds 'n leidende rol by 'n voedingskema wat kos aan die armstes van die armes voorsien. Saam met die Gereformeerde Kerk Uitkyk is hy ook by die vestiging van groentetuine in die informele woongebiede betrokke. Hier word armes aangemoedig om hulle eie groente en vrugte te kweek, ten einde selfonderhoudend te word en 'n gesonde dieet te volg.

Die toerusting van plaaslike leraars in die Mafikengomgewing dien as nog'n voorbeeld van Sarel se gemeenskapsbetrokkenheid. Deur middel van verskeie leraarskonferensies wat aangebied is, het Sarel saam met sy kollegas plaaslike leraars die geleentheid gebied om hulleself teologies verder toe te rus. By hierdie geleenthede is die werk van die Departement ook bekendgestel en dit het daartoe gelei dat verskeie van die leraars hulle vir akademiese studie ingeskryf het.

\section{Gesins- en persoonlike lewe}

Sarel is in 1974 met Belia (gebore Booyens) wat hy gedurende sy universiteitstudie ontmoet het, getroud. Sedert die begin van sy loopbaan as leraar en akademikus het sy hom bygestaan en ondersteun. Belia wat self ook 'n doktorsgraad in Afrikaanse letterkunde het, het die meeste van haar tyd aan die opvoeding van hulle drie kinders, Danie, Kobus en Joanette spandeer.

Sarel en Belia is met ses kleinkinders geseën, aan wie hulle baie geheg is. Hulle lê gereeld groot afstande af om die kleinkinders te sien en hulle ontwikkeling te geniet. Gedurende 2017 was hulle ook bevoorreg om te beleef dat hulle dogter Joanette 'n doktorsgraad in Taalkunde en Literêre Teorie verwerf het.
Gedurende sy verblyf in Namibië het Sarel twee stokperdjies ontwikkel waarvoor hy besonder lief geraak het, naamlik jag en vlieg. Alhoewel Sarel graag vir ontspanning gejag het, het hy leer vlieg uit praktiese oorwegings as gevolg van die groot afstande wat hy in die uitvoering van sy pligte as leraar moes aflê. Gevolglik het hy homself as vlieënier bekwaam en sy eie ligte vliegtuig bekom. Sedertdien het Sarel baie vliegure afgelê en selfs 'n noodlanding of twee in die uitvoering van sy pligte oorleef! Hy geniet steeds hierdie stokperdjie saam met sy seuns wat sy liefde vir vlieg deel. Hulle neem gereeld aan die jaarlikse Presidentsbeker Wedvlug deel. In 1995 het Sarel die wedren saam met Mike Howel gewen en in 2016 kom Sarel en sy seun Kobus tweede in die wedvlug.

\section{Impak en nalatenskap}

In die lig daarvan dat Sarel oor die jare soveel in onderrig belê het, moet sy nalatenskap in die impak wat hy in die lewens van sy studente gemaak het, gesoek word. Baie van die studente wat by die Departement vir studie ingeskryf het, het uit moeilike omstandighede gekom. As programleier was Sarel die eerste persoon wat hulle ontmoet het. Wanneer studente egter van hulle roeping oortuig was, het Sarel alles in sy vermoë gedoen om hulle by te staan, selfs al het dit beteken dat hy van sy persoonlike hulpbronne moes aanwend. Een so 'n getuienis is die huldeblyk wat een van Sarel se studente oor hom na sy aftrede, ${ }^{3}$ geskryf het. In hierdie huldeblyk verwys hy na Sarel as 'God se boodskapper', 'n 'vader' en 'mentor'. Ons neem die vrymoedigheid om met sy toestemming, 'n paragraaf uit die huldeblyk aan te haal, aangesien dit die impak wat Sarel op hierdie student se lewe gehad het, ten beste beskryf:

'As I pay tribute to Prof. Sarel van der Merwe, it won't be complete if I do not mention that I only paid R75.00 for my entire academic life. The rest of the tuition was sponsored. Until today I don't know who did that. I never asked, but he always gave me my registration certificates. I have a library now which can be classified as an academic one due to his generosity and caring. I have managed to go through life by his guidance and care.'

Sarel se grootste nalatenskap is dus te vind in die lewens van die studente vir wie hy dit moontlik gemaak het om hulle roeping uit te leef deur Teologie te studeer. Nog 'n nalatenskap is natuurlik die Departement Teologie op die Mafikengkampus wat sy bestaan te danke het aan 'n persoon wat deur sy lewe as leraar, sendeling en akademikus die missio Dei op 'n praktiese wyse vergestalt het.

3. Huldeblyk deur Dr Phemelo Marumo, eerste PhD-gegradueerde van die Department van Teologie en tans dosent in Filosofie aan die Fakulteit van Menslike en Sosiale Wetenskappe op die Mafikengkampus. 